\title{
PERSEPSI NELAYAN TERHADAP TEMPAT PEMASARAN IKAN HIGIENIS DI PELABUHAN PERIKANAN SAMUDERA CILACAP
}

\section{Fishers Perception on Hygienic Fish Market at Cilacap fishing port}

\author{
*Muhammad Rizqi Hasani, Djoko Suprapto, dan Dian Wijayanto \\ Fakultas Perikanan dan IImu Kelautan, Universitas Diponegoro Semarang \\ JI. Prof. H. Soedarto, S.H, Tembalang, Kec. Tembalang, Kota Semarang, Jawa Tengah 50275, Indonesia \\ Diterima tanggal: 7 Juli 2019; Diterima setelah perbaikan: 26 Februari 2020; \\ Disetujui terbit: 30 Juni 2020
}

\begin{abstract}
ABSTRAK
Kualitas hasil perikanan dipengaruhi oleh kondisi tempat pemasaran ikan di pelabuhan perikanan. Penunjang utama keberhasilan peningkatan mutu di Pelabuhan Perikanan Samudra (PPS) yaitu dengan membuat konsep pemasaran ikan higienis, salah satunya di PPS Cilacap. Pembangunan tempat pemasaran ikan (TPI) higienis PPS Cilacap ini dilandasi oleh Keputusan Direktorat Jendral Perikanan Tangkap (DJPT) no 7 tahun 2017 tentang petunjuk teknis TPI higienis di pelabuhan perikanan. Tujuan penelitian adalah mengkaji dan mendeskripsikan persepsi penguna jasa terhadap penerapan tempat pemasaran ikan higienis dengan metode analisis bersifat deskriptif. Hasil penelitian ini menunjukan bahwa persepsi pengguna jasa terhadap tempat pemasaran ikan higienis di PPS Cilacap dari aspek fasilitas mayoritas penerapan tinggi yaitu nilainya di atas 146,67, akan tetapi kondisi (lantai, ventilasi, fasilitas/peralatan penunjang pemasaran higienis) beberapa dinilai rendah yaitu kurang dari 93,33 dan fasilitas seperti roller conveyor, cool box, mesin penghancur es (ice crusher) tidak terdapat di PPS Cilacap. Aktivitas bongkar dan pengangkutan juga memiliki rata-rata persepsi dalam penerapan tinggi yaitu nilainya diatas 146,67 . Penanganan ikan di TPI higienis PPS Cilacap tidak dilakukan pelelangan, tidak dilakukan pensotiran di meja sortir dan pelabelan. Partisipasi nelayan dalam pemasaran menjadi berkurang akibat tidak diadakannya pelelangan. Oleh karena itu perlu dilakukan perbaikan penerapan, baik fasilitas yang sudah mulai mengalami kerusakan, serta perlunya penambahan fasilitas untuk memperlancar aktivitas.
\end{abstract}

Kata Kunci: persepsi nelayan; pemasaran ikan; TPI higienis; kondisi fasilitas; penerapan higienitas

\begin{abstract}
The quality of fisheries products subject to condition of the fish market. The key concept of fish quality at Cilacap was fishing port due to the existence of hygienic fish market. Decision Letter of the Director General of Capture Fisheries No.7/2017 regarding the technical guidelines for hygienic fish market at the fishing port has been the basis of the development of hygienic fishing port in Cilacap. This study aimed to asses and describe public perception on the hygienic fish market using a descriptive method. The study showed that public perception on hygienic fish market at Cilacap fishing port was above 146.67 in terms of its facilities. The condition of some facilities (flooring, ventilation, facilities or other equipment that support hygienic marketing) were classified under 93.33, while some equipment such as roller conveyor, cool box, ice crusher were not available at Cilacap fishing port. Unloading and transportation presented a high average perception in the application above 146.67. There are no auction, sorting on the sorting table, and labelling in the fish handling at hygienic fishing port since there is no auction Cilacap. There was a decreased participation of fishers in fish marketing. Therefore, it is necessary to improve application of hygienic fish handling by repairing the damaged facilities and establishing more additional equipment.
\end{abstract}

Keywords: fisher's perception; fish marketing hygienic; facility conditions;application of hygiene 


\section{PENDAHULUAN}

Pada tahun 2017, Kementerian Kelautan dan Perikanan (KKP) mulai melakukan pembenahan kembali dalam pengembangan pelabuhan perikanan yang higienis dengan merumuskan petunjuk teknis tempat pemasaran ikan (TPI) higienis di pelabuhan perikanan dengan Nomor peraturan 7/PER-DJPT/2017. Pelabuhan Perikanan Samudera (PPS) Cilacap menjadi salah satu di antara pelabuhan yang menerapkan pengembangan tempat pemasaran ikan higienis tersebut. Pengertian higienis pangan menurut Codex Alimentarius Commission (2009) adalah semua kondisi serta tindakan yang perlu dilakukan untuk menjamin keamanan dan kelayakan makanan pada semua tahapan. Menurut KBBI (2019) higienis berkaitan dengan ilmu kesehatan; kebersihan; dan bebas penyakit. Sedangkan menurut DJPT (2017) higiene adalah upaya dan persyaratan dalam mengendalikan bahaya dan memastikan keamanan makanan bagi manusia bila dikonsumsi sesuai tujuan penggunaan.

Pelabuhan perikanan merupakan prasarana penunjang dalam meningkatkan usaha perikanan, pusat pengembangan masyarakat nelayan, juga pusat berbagai macam kegiatan ekonomi perikanan seperti (produksi, pengolahan, pemasaran hasil perikanan dan pangkalan kapal perikanan) (Suherman, Rosyid \& Boesono, 2012).

Penerapan TPI higienis PPS Cilacap penting untuk dilihat kegiatan operasional dan fasilitas yang ada dipelabuhan tersebut. Menurut Nugraheni, Rosid \& Boesono (2013) aktivitas pelabuhan perikanan umumnya dimulai dari aktivitas pendaratan ikan, pengolahan ikan, hingga aktivitas pemasaran ikan. Fasilitas pelabuhan perikanan antara lain fasilitas dasar, fasilitas fungsional, dan fasilitas penunjang.

TPI higienis adalah pengembangan dari program minapolitan. Menurut Pancawati (2015) pelaksanaan minapolitan di Kabupaten Cilacap, baik dari Dinas Kelautan, Perikanan dan Pengelola Sumber Daya Kawasan Segara Anakan (DKP2SKSA) Kabupaten Cilacap dan PPS Cilacap selaku Tim Pokja Minapolitan kurang berkoordinasi dengan baik. Selanjutnya Nastiti, Wibowo \& Dewi (2017) menyatakan belum maksimalnya kinerja layanan jasa kesyahbandaran di PPS Cilacap.

Perkembangan komoditas produk perikanan di pasar domestik mengalami pengembangan dan perluasan pemasaran (Mintoro \& Haryadi,
2013). Berkaitan dengan itu penerapan sistem manajeman mutu menjadi suatu keputusan stategis untuk organisasi dalam meningkatkan kinerja untuk pembangunan berkelanjutan (ISO, 2015). Peran pelaku bisnis, jaringan sosial dan pertukaran sosial juga menjadi dasar dalam menyusun kebijakan revitalisasi pelabuhan (Zulham, 2016).

Berkaitan dengan penyelengaraan program TPI higienis beberapa peraturan tentang jaminan mutu juga sudah ditetapkan oleh pemerintah di dalam Peraturan Pemerintah No. 57 tahun 2015 tentang Sistem Jaminan Mutu dan Keamanan Hasil Perikanan serta Peningkatan Nilai Tambah Produk Hasil Perikanan serta Keputusan Menteri Kelautan dan Perikanan No.52A tahun 2013 tentang Persyaratan Jaminan Mutu dan Keamanan Hasil Perikanan pada Proses Produksi, Pengolahan dan Distribusi. Kemudian Direktorat Jenderal Perikanan Tangkap (2017) merumuskan ruang lingkup Tempat Pemasaran Ikan (TPI) higienis meliputi: (a). Persyaratan umum TPI higienis (bangunan); (b). Pengaturan operasional sanitasi TempatPemasaran Ikan (TPI) Higienis; (c). Aktivitas pembongkaran ikan; (d). Aktivitas pengangkutan ikan; (e). Aktivitas penanganan ikan di Tempat Pemasaran Ikan (TPI) Higienis; dan (f). Monitoring dan evaluasi.

Berdasarkan latar belakang dan permasalahan di atas maka dalam rangka peningkatan usaha perikanan, program pemasaran higienis memiliki peluang dalam peningkatan tersebut. Berkaitan dengan hal tersebut diperlukan konsep yang sesuai dengan daerah basis perikanan setiap daerah, oleh karena itu penelitian ini bertujuan untuk mengkaji dan mendeskripsikan persepsi pengguna jasa terhadap TPI higienis PPS Cilacap.

\section{METODOLOGI}

Penelitian mengunakan kebijakan/peraturanperaturan yang berkaitan dengan penerapan TPI higienis PPS Cilacap sebagai dasar pengambilan data. Data yang diambil berupa pengamatan langsung dilokasi penelitian berupa kondisi fasilitas dan kondisi aktivitas serta wawancara terhadap nelayan dan pengelola TPI untuk memperoleh persepsi terhadap TPI higienis PPS Cilacap.

\section{Lokasi dan waktu}

Penelitian dilakukan pada bulan Maret- 
Mei 2019 di TPI higienis PPS Cilacap, Jawa Tengah.

\section{Jenis dan Metode Pengambilan Data}

Teknik pengambilan data yang digunakan dalam pengambilan penelitian ini adalah observasi dan wawancara terhadap responden. Penentuan responden mengenai persepsi pengguna jasa di TPI higienis PPS Cilacap dilakukan secara purposive sampling dengan jumlah 40 orang responden, terdiri dari nelayan sebanyak 25 orang responden dan pengelola TPI berjumlah 15 orang. Responden diperoleh dari orang yang berhubungan langsung dengan pengunaan TPI higienis. Menurut Sugiyono (2015) pengertian purposive sampling adalah teknik penentuan sampel dengan pertimbangan tertentu. Penelitian ini dilakukan dengan maksud untuk mengkaji dan mendeskripsikan persepsi pengguna jasa (nelayan dan pengelola) terhadap TPI higienis PPS Cilacap.

\section{Metode Analisis}

Analisis data yang digunakan dalam penelitian ini adalah deskriptif, bertujuan untuk menjelaskan persepsi pengguna jasa dalam penerapan TPI higienis PPS Cilacap berdasarkan acuan DJPT no 7 tahun 2017 tentang petunjuk teknis tempat pemasaran ikan (TPI) higienis di pelabuhan perikanan. Hasil kuisioner kemudian diolah dengan menggunakan perhitungan frekuensi melalui program SPSS 23 (Statistical Product and Service Solution). Langkah yang ditempuh adalah sebagai berikut: (a) Memperoleh informasi kondisi TPI Higienis PPS Cilacap; (b) Perolehan data persepsi penguna jasa terhadap TPI higienis PPS Cilacap, dan; (c) Kesimpulan didapatkan dengan analisis diskriptif terhadap hasil perolehan informasi dan data persepsi TPI higienis PPS Cilacap.

Hasil kuesioner diukur dengan memberikan skor untuk jawaban alternatif pada setiap item adalah sebagai berikut:

- Skor 5 untuk jawaban sangat baik.

- Skor 4 untuk jawaban baik.

- Skor 3 untuk jawabannya cukup.

- Skor 2 untuk jawaban buruk.

- Skor 1 untuk jawaban sangat buruk.

Interpretasi skor menggunakan rumus Sugiyono (2012) Nilai Kriterium = Skala Nilai $\mathrm{x}$ Jumlah Responden, diperoleh hasil klasifikasi:

- $40 \times 5=200$

- $40 \times 4=160$

- $40 \times 3=120$
- $40 \times 2=80$

- $40 \times 1=40$

Jumlah skor ideal untuk setiap item pertanyaan (skor tertinggi) $=200$ dan jumlah (skor terendah $)=40$. Kategori penerapan didapatkan dari hasil tersebut yang kemudian dikompositkan, sehingga didapat nilai skor komposit yaitu 160, selanjutnya di bagi menjadi tiga selang nilai yaitu 160/3 = 53,33 sehingga nilainya:

$\begin{array}{ll}\text { Rendah } & =40,00 \text { sampai } 93,33 \\ \text { Sedang } & =93,34 \text { sampai } 146,66 \\ \text { Tinggi } & =146,67 \text { sampai } 200,00\end{array}$

\section{HASIL DAN PEMBAHASAN}

\section{Kondisi Umum}

Kabupaten Cilacap menurut BPS (2017) merupakan kabupaten terluas di Jawa Tengah, berada pada koordinat 108 '4' 30" - 109 '30' 30" BT dan $7^{\circ} 30^{\prime}$ - $7^{\circ} 45^{\prime} 20^{\prime \prime}$ LS, dengan luas wilayah $225.361 \mathrm{Ha}$ dan terbagi menjadi 24 kecamatan. Perbatasan Kabupaten Cilacap yaitu: Sebelah Selatan: Samudra Indonesia; Sebelah Utara: Kabupaten Banyumas; Sebelah Timur: Kabupaten Kebumen; dan Sebelah Barat: Provinsi Jawa Barat.

Pembangunan Pelabuhan Perikanan Samudra Cilacap pertama kali dimulai pada tahun 1990 kemudian resmi penggunaannya pada tahun 1996 dengan status kelembagaan pelabuhan perikanan type $\mathrm{B}$ atau dengan nama Pelabuhan Perikanan Nusantara Cilacap. Seiring perkembangannya selanjutnya pada tanggal 4 April 2001 statusnya ditingkatkan menjadi Pelabuhan Perikanan Tipe A atau Samudera.

Menurut Suherman (2010) Pelabuhan Perikanan adalah pusat aktivitas perekonomian kelautan, sehingga keberadaannya sangat diperlukan dalam pembangunan perikanan dan kelautan. Selanjutnya menurut Sarwanto, Wiyono, Nurani \& Haluan (2014) menyatakan bahwa penyempurnaan sistem informasi pemasaran ikan di TPI perlu ditingkatkan untuk menunjang kegiatan pemasaran. Melihat pada Tabel 1 saat ini nilai produksi PPS Cilacap cenderung naik, kedua hal tersebut perlu di pertimbangkan dalam penerapan Pelabuhan Perikanan Samudra Cilacap.

Hasil produksi menunjukan nilai produksi yang terus meningkat dari tahun 2014-2018. Nilai produksi tersebut menjadi salah satu faktor 
Tabel 1. Produksi perikanan PPS Cilacap Tahun 2014 - 2018.

Table 1. Fishery production PPS Cilacap 2014 - 2018.

\begin{tabular}{cccc}
\hline No & Tahun/Year & $\begin{array}{c}\text { Produksi (Ton)/ } \\
\text { Production Year (Ton) }\end{array}$ & $\begin{array}{c}\text { Nilai Produksi (Rp)/ Production } \\
\text { Value (IDR) }\end{array}$ \\
\hline 1. & 2014 & $5,737,640$ & $117,689,250$ \\
2. & 2015 & $13,317,710$ & $251,091,180$ \\
3. & 2016 & $7,966,550$ & $202,444,020$ \\
4. & 2017 & $11,840,410$ & $241,763,440$ \\
5. & 2018 & $15,216,850$ & $278,853,000$ \\
\hline
\end{tabular}

Sumber: Pelabuhan Perikanan Samudra Cilacap, 2019/ Source: Ocean Fishing Port Cilacap, 2019

PPS Cilacap pada tahun 2017 ditunjuk oleh Kementerian Kelautan dan Perikanan untuk menjadi salah satu pelabuhan perikanan yang mengarah ke penerapan higienitas perikanan supaya lebih baik. PPS Cilacap kemudian dibangun suatu tempat pemasaran ikan higienis yang didirikan pada 28 April 2018. Program tersebut dirancang berdasarkan pada keputusan DJPT no 7/PER-DJPT/2017 tentang Petunjuk Teknis Tempat Pemasaran Ikan (TPI) Higienis di Pelabuhan Perikanan.

Pemberian kebijakan di bidang perikanan seharusnya berdampak positif terhadap kegiatan yang dilakukan, tetapi perbaikan penerapan kebijakan juga penting diselaraskan dengan kebijakan, sehingga manfaat dapat dirasakan oleh masyarakat nelayan (Ningsih, Irnad \& Cahyadinata, 2017). Faktor yang harus ditinjau dalam perencanaan sebuah bangunan berstandar higienis yaitu: lingkungan; manusia; dan bangunan itu sendiri (Marcella, Prawata \& Nasir, 2013). Selanjutnya didalam perubahan karakteristik, nelayan perlu melakukan pelatihan kebersihan sebagai dasar penanganan ikan serta dasar memahami resiko keamanan pangan (Singh, Santhakumar, Pandey, Bharati \& Roy, 2012).

Persepsi Terhadap Penerapan TPI Higienis PPS

\section{Cilacap}

Penerapan tempat pemasaran ikan higienis ini sangat tergantung pada sarana prasarana dan dukungan dari masyarakat nelayan sebagai penguna jasa. Sejalan dengan itu menurut Sutrisno (2014) kebijakan pemerintah yang berpihak pada lingkungan hidup dan masyarakat serta penyediaan sarana dan prasarana demi menunjang aktivitas nelayan sangat dibutuhkan. Tidak dapat dipungkiri persepsi masyarakat terhadap TPI di Indonesia yaitu kotor seperti dikatakan Lubis (2012) kondisi umum pelabuhan perikanan di Indonesia masih dipandang kotor dan kumuh. Selain itu menurut Wahyudi, Lubis \& Pane (2017) menyatakan banyak ditemukan permasalahan terkait sanitasi dan higienitas yang buruk di pelabuhan perikanan.

Kondisi sanitasi di TPI akan berdampak pada kualitas produksi perikanan (Asmal, Amina \& Alia, 2016). Selanjutnya kunci keberhasilan penerapan manajemen dalam rangka pemanfaatan sumber daya perikanan yang berkesinambungan terletak pada dukungan dari masyarakat sebagai pelaku utama (Mussadun, Kusumastanto \& Kamal, 2011). sehingga penelitian ini berfokus pada persepsi penguna jasa terhadap kondisi fasilitas dan aktivitas TPI higienis PPS Cilacap dengan acuan

Tabel 2. Persepsi Kondisi Bangunan.

Table 2. Perception of Building Conditions.

\begin{tabular}{|c|c|c|c|c|c|}
\hline No & $\begin{array}{c}\text { Uraian/ } \\
\text { Description }\end{array}$ & $\begin{array}{l}\text { Frekuensi/ } \\
\text { Frequency }\end{array}$ & $\begin{array}{l}\text { Responden/ } \\
\text { Respondents }\end{array}$ & $\begin{array}{l}\text { Persen(\%)/ } \\
\text { Percent (\%) } \\
\end{array}$ & $\begin{array}{l}\text { Jumlah total/ } \\
\text { Total Amount }\end{array}$ \\
\hline \multirow[t]{2}{*}{1.} & \multirow[b]{2}{*}{$\begin{array}{l}\text { Kondisi bangunan Tempat Pemasaran } \\
\text { (minimal memiliki area bongkar; } \\
\text { area sortir; area penimbangan; dan } \\
\text { area display)/ The condition of the } \\
\text { building where the Marketing Place } \\
\text { has a minimum (loading area; sorting } \\
\text { area;weighing area; and display area) }\end{array}$} & Baik/ Good & 29 & 72.5 & \multirow[t]{2}{*}{171 (Tinggi/High) } \\
\hline & & $\begin{array}{l}\text { Sangat baik/ Very } \\
\text { Good }\end{array}$ & 11 & 27.5 & \\
\hline \multirow[t]{3}{*}{2.} & \multirow{3}{*}{$\begin{array}{l}\text { Konstruksi bangunan dapat mencegah } \\
\text { bersarangnya burung, serangga dan } \\
\text { binatang pengerat/ Building construction } \\
\text { can prevent the nesting of birds, insects } \\
\text { and rodents. }\end{array}$} & Cukup /Enough & 8 & 20.0 & \multirow[t]{3}{*}{162 (Tinggi/High) } \\
\hline & & Baik / Good & 22 & 55.0 & \\
\hline & & $\begin{array}{l}\text { Sangat baik/ Very } \\
\text { Good }\end{array}$ & 10 & 25.0 & \\
\hline
\end{tabular}


Tabel 3. Persepsi Kondisi Dinding.

Table 3. Perception of Wall Conditions.

\begin{tabular}{|c|c|c|c|c|}
\hline $\begin{array}{c}\text { Uraian/ } \\
\text { Description }\end{array}$ & $\begin{array}{l}\text { Frekuensi/ } \\
\text { Frequency }\end{array}$ & $\begin{array}{l}\text { Responden/ } \\
\text { Respondents }\end{array}$ & $\begin{array}{l}\text { Persen (\%)/ } \\
\text { Percent (\%) }\end{array}$ & $\begin{array}{l}\text { Jumlah Total/ } \\
\text { Total Amount }\end{array}$ \\
\hline \multirow{3}{*}{$\begin{array}{l}\text { Kondisi dinding dan pelindung } \\
\text { di tempat pemasaran (ditinjau } \\
\text { dari bahan dan kontruksi)./ } \\
\text { The condition of the walls and } \\
\text { protective fence in the marketing } \\
\text { area (in terms of materials and } \\
\text { construction). }\end{array}$} & $\begin{array}{l}\text { Cukup/ } \\
\text { Enough }\end{array}$ & 7 & 17.5 & 167 (Tinggi/ High) \\
\hline & Baik/ Good & 19 & 47.5 & \\
\hline & $\begin{array}{l}\text { Sangat } \\
\text { baik/ Very } \\
\text { Good }\end{array}$ & 14 & 35.0 & \\
\hline
\end{tabular}

DJPT No 7 tahun 2017. Hasil yang didapat pada wawancara dan observasi dapat dilihat pada Tabel 2.

Persepsi terhadap kondisi bangunan tempat pemasaran ikan pada Tabel 2 menunjukan nilai penerapan tinggi dan jawaban terbanyak adalah kondisinya baik. Kondisi bangunan di TPI Higienis PPS Cilacap memiliki area bongkar, penimbangan, pensortiran, dan display. Kontruksi pada bangunan TPI rapat sehingga menghalangi binatang masuk ke area dalam gedung. Supaya mendukung persyaratan banguanan TPI juga dilengkapi dengan fasilitas parkir kendaraan, gudang kantor pengelola dan kantor KUD demi mempermudah kelancaran aktivitas. Penerapan TPI ini walaupun sudah memiliki bangunan yang tertutup akan tetapi saat aktivitas berjalan pintu masuk maupun pintu keluar akan dibuka, menyebabkan bangunan dapat dimasuki oleh hewan seperti kucing dan burung.

Indikator penilaian ditinjau dari kondisi dinding dan pelindung didapatkan hasil penerapan tinggi dengan skor 167 (Tabel 3). Kondisi pada TPI higienis PPS Cilacap saat penelitian dilakukan yaitu keadaan dinding bersih dengan bahan terbuat dari kramik sehingga tidak menyerap air, kering, dengan permukaan rata dan halus, tidak lembab, berwarna cerah dipasang rata tanpa celah sehinga memudahkan saat dibersihkan.

Kondisi lantai dilihat dari bahan dan kebersihan lantai didapatkan skor penerapan sedang atau dalam kondisi cukup (Tabel 4). Lantai yang dimiliki oleh TPI higienis PPS Cilacap berbahan keramik yang sebelumnya dilapisi porselen, akan tetapi kondisi saat ini sudah banyak yang terkelupas dan dianggap oleh para pengguna jasa terlalu miring, kemiringan $\pm 5^{\circ}$ kearah saluran pembuangan. Pada saat penelitian berlangsung lantai dibeberapa bagian pecah menjadikan lantai memiliki genagan dan susah dibersihkan. Pada keseluruhan kondisi lantai tidak berpori, kedap air, pertemuan antar lantai dan dinding melengkung serta mempunyai ketinggian yang lebih tinggi \pm 1 meter dari tanah sehingga memudahkan dalam pengangkutan ke atas truk pengangkut.

Jumlah skor pada kondisi saluran pembuangan ditinjau dari bahan dan konstruksi memiliki skor penerapan tinggi atau kebanyakan menyatakan kondisinya baik (Tabel 5). Kondisi saluran pembuangan TPI higienis PPS Cilacap berbentuk "U" dan terpasang pula jeruji besi untuk menahan binatang pengerat masuk. Bahan dari saluran pembuangan ini adalah gorong-gorong yang tidak dilapisi apapun sehingga permukaan

Tabel 4. Persepsi Kondisi Lantai.

Table 4. Perception of Floor Conditions.

\begin{tabular}{|c|c|c|c|c|c|}
\hline No & $\begin{array}{c}\text { Uraian/ } \\
\text { Description }\end{array}$ & $\begin{array}{l}\text { Frekuensi/ } \\
\text { Frequency }\end{array}$ & $\begin{array}{l}\text { Responden/ } \\
\text { Respondents }\end{array}$ & $\begin{array}{l}\text { Persen (\%)/ } \\
\text { Percent (\%) }\end{array}$ & $\begin{array}{l}\text { Jumlah Total/ } \\
\text { Total Amount }\end{array}$ \\
\hline \multirow[t]{3}{*}{1.} & \multirow{3}{*}{$\begin{array}{l}\text { Kondisi lantai (ditinjau dari bahan dan } \\
\text { kebersihan lantai)/ Floor condition } \\
\text { (in terms of floor material and } \\
\text { cleanliness) }\end{array}$} & Buruk/ Bad & 9 & 22.5 & \multirow[t]{3}{*}{$\begin{array}{c}124 \text { (Sedang/ } \\
\text { Medium })\end{array}$} \\
\hline & & Cukup/Enough & 18 & 45.0 & \\
\hline & & Baik/ Good & 13 & 32.5 & \\
\hline \multirow[t]{2}{*}{2.} & \multirow{2}{*}{$\begin{array}{l}\text { Konstruksi Lantai (ditinjau dari } \\
\text { kontruksi antar lantai dan kemiringan } \\
\text { kearah saluran pembuangan)/ Floor } \\
\text { Construction (in terms of construction } \\
\text { between floors and slope of the floor } \\
\text { towards the drain) }\end{array}$} & Cukup/ Enough & 29 & 72.5 & \multirow[t]{2}{*}{$\begin{array}{c}131 \text { (Sedang/ } \\
\text { Medium })\end{array}$} \\
\hline & & Baik/ Good & 11 & 27.5 & \\
\hline
\end{tabular}


Tabel 5. Persepsi Kondisi Saluran Pembuangan.

Table 5. Perception of Channel Dischargeconditions.

\begin{tabular}{llccc}
\hline \multicolumn{1}{c}{$\begin{array}{c}\text { Uraian/ } \\
\text { Description }\end{array}$} & \multicolumn{1}{c}{$\begin{array}{c}\text { Frekuensi/ } \\
\text { Frequency }\end{array}$} & $\begin{array}{c}\text { Responden/ } \\
\text { Respondents }\end{array}$ & $\begin{array}{c}\text { Persen (\%)/ } \\
\text { Percent (\%) }\end{array}$ & $\begin{array}{c}\text { Jumlah Total/ } \\
\text { Total Amount }\end{array}$ \\
\hline $\begin{array}{l}\text { Kondisi saluran pembuangan } \\
\text { (Ditinjau dari bahan dan konstruksi)/ } \\
\text { Drain Condition (in terms of } \\
\text { materials and construction) }\end{array}$ & Cukup/ Enough & 2 & 5.0 & 162 (Tinggi/ High) \\
\cline { 2 - 5 } & Baik/ Good & 34 & 85.0 & \\
\cline { 2 - 5 } & $\begin{array}{l}\text { Sangat baik/ Very } \\
\text { Good }\end{array}$ & 4 & 10.0 & \\
\hline
\end{tabular}

berpori dan tidak rata, namun saat wawancara petugas kebersihan mengatakan masih tergolong mudah dibersihkan.

Kondisi atap ditinjau dari konstruksi dan ventilator dalam melindungi produk didapatkan skor 169 atau memiliki kondisi baik (Tabel 6). Atap pada TPI higienis PPS Cilacap memiliki kontruksi yang miring dan mempunyai 10 ventilator roof yang terpasang di atas atap. Jarak antara lantai dan atap berjauhan serta bahan atap kuat, sehingga diharapkan bisa melindungi produk dari kotoran, hujan, panas matahari, dan tidak mengakibatkan kontaminasi produk.

Hasil kondisi penerangan ditinjau dari pelindung dan intensitas cahaya tidak menyilaukan mata memiliki penerapan tinggi dengan skor 163 atau kebanyakan sebesar $63,5 \%$ mengkategorikan baik (Tabel 7). Kondisi pencahayaan pada TPI higienis PPS Cilacap memiliki pencahayaan yang sudah baik atau tidak mengangu aktivitas penaganan ikan serta lampu penerangan memiliki pelindung untuk menghindari pecahnya lampu yang dapat mengkontaminasi produk.

Hasil kondisi penerangan ditinjau dari pelindung dan intensitas cahaya tidak menyilaukan mata memiliki penerapan tinggi dengan skor 163 atau kebanyakan sebesar $63,5 \%$ mengkategorikan baik (Tabel 7). Kondisi pencahayaan pada TPI higienis PPS Cilacap memiliki pencahayaan yang sudah baik atau tidak mengangu aktivitas penaganan ikan serta lampu penerangan memiliki pelindung untuk menghindari pecahnya lampu yang dapat mengkontaminasi produk.

Kondisi sirkulasi udara didalam TPI ditinjau dari sirkulasi untuk membuang udara dan menjaga suhu antara $28-32^{\circ} \mathrm{C}$ dinilai cukup oleh penguna jasa dengan 20 orang menyatakan baik (Tabel 8). Hasil penerapannya sedang. Hasil ini diperoleh karena Kondisi sirkulasi udara pada TPI higienis PPS Cilacap dibantu dengan membuka pintu masuk dan keluar pada saat aktivitas pemasaran berlangsung. Hal ini disebabkan karena kurangnya fasilitas pendukung siirkulasi udara. Sirkulasi udara pada TPI higienis

Tabel 6. Persepsi Kondisi Atap.

Table 6. Perception of Roof Conditions.

\begin{tabular}{llccc}
\hline \multicolumn{1}{c}{$\begin{array}{c}\text { Uraian/ } \\
\text { Description }\end{array}$} & $\begin{array}{c}\text { Frekuensi/ } \\
\text { Frequency }\end{array}$ & $\begin{array}{c}\text { Responden/ } \\
\text { Respondents }\end{array}$ & $\begin{array}{c}\text { Persen (\%)/ } \\
\text { Percent (\%) }\end{array}$ & $\begin{array}{c}\text { Jumlah total/ } \\
\text { Total Amount }\end{array}$ \\
\hline $\begin{array}{l}\text { Kondisi Atap (Ditinjau dari konstruksi } \\
\text { atap yang melindungi produk dan } \\
\begin{array}{l}\text { ventilator)/ Roof Conditions (In terms } \\
\text { of construction that protects the } \\
\text { product and ventilator) }\end{array}\end{array}$ & Baik/ Good & 31 & 77.5 & 169 (Tinggi/High) \\
\cline { 2 - 5 } & Sangat Baik/ & 9 & 22.5 & \\
\hline
\end{tabular}

Tabel 7. Persepsi Kondisi Penerangan.

Table 7. Perception of Lighting Conditions.

\begin{tabular}{|c|c|c|c|c|}
\hline $\begin{array}{c}\text { Uraian/ } \\
\text { Description }\end{array}$ & $\begin{array}{l}\text { Frekuensi/ } \\
\text { Frequency }\end{array}$ & $\begin{array}{l}\text { Responden/ } \\
\text { Respondents }\end{array}$ & $\begin{array}{l}\text { Persen (\%)/ } \\
\text { Percent (\%) }\end{array}$ & $\begin{array}{l}\text { Jumlah Total/ } \\
\text { Total Amount }\end{array}$ \\
\hline \multirow{3}{*}{$\begin{array}{l}\text { Kondisi Penerangan (ditinjau dari bahan, } \\
\text { pelindung dan intensitas cahaya)/ Lighting } \\
\text { Conditions (in terms of materials, lamp } \\
\text { shades and light intensity) }\end{array}$} & $\begin{array}{l}\text { Cukup/ } \\
\text { Enough }\end{array}$ & 6 & 15.0 & $\begin{array}{c}163 \text { (Tinggi/ } \\
\text { High) }\end{array}$ \\
\hline & Baik/ Good & 25 & 62.5 & \\
\hline & $\begin{array}{l}\text { Sangat baik/ } \\
\text { Very Good }\end{array}$ & 9 & 22.5 & \\
\hline
\end{tabular}


Tabel 8. Persepsi Ventilasi dan Sirkulasi Udara.

Table 8. Perception of ConditionsVentilation and Circulation.

\begin{tabular}{llccc}
\hline \multicolumn{1}{c}{$\begin{array}{c}\text { Uraian/ } \\
\text { Description }\end{array}$} & $\begin{array}{c}\text { Frekuensi/ } \\
\text { Frequency }\end{array}$ & $\begin{array}{c}\text { Responden/ } \\
\text { Respondents }\end{array}$ & $\begin{array}{c}\text { Persen (\%) } \\
\text { Percent (\%) }\end{array}$ & $\begin{array}{c}\text { Jumlah Total } \\
\text { Total Amount }\end{array}$ \\
\hline $\begin{array}{l}\text { Kondisi sirkulasi udara didalam } \\
\text { Tempat Pemasaran Ikan. / }\end{array}$ & Buruk/ Bad & 3 & 7,5 & $\begin{array}{c}\text { 134 (Sedang/ } \\
\text { Medium) }\end{array}$ \\
\cline { 2 - 5 } $\begin{array}{l}\text { Condition of air circulation in the } \\
\text { fish market }\end{array}$ & Cukup/ Enough & 20 & 50,0 & \\
\cline { 2 - 5 } & Baik/ Good & 17 & 42,5 & \\
\hline
\end{tabular}

PPS cilacap hanya menggunakan ventilator roof saja sehingga pada saat pemasaran berlangsung suhu akan naik dan udara menjadi penggap.

Hasil persepsi mengenai kondisi peralatan penunjang seperti pada Tabel 9 menyatakan penerapan tinggi di pengelolaan limbah dan kondisi instalasi air bersih saja, selain itu penerapannya dinyatakan sedang hasil observasi Fasilitas penunjang di TPI higienis PPS Cilacap dinilai cukup lengkap dengan adanya: (a) Meja sortir dengan bahan kramik namun kondisi dibeberapa bagian mulai retak; (b) Tempat cuci tangan didalam gedung; (c) WC diletakkan diluar ruang TPI sehingga tidak mengkontaminasi produk; (d) Pengelolaan limbah sampah yang sudah dibedakan menurut jenis tetapi jaraknya jauh dari TPI; (e) Air bersih yang mencukupi kebutuhan aktivitas pemasaran, dan; (f) Tidak memiliki penanganan air limbah yang baik.

Pada TPI higienis PPS Cilacap Kondisi peralatan penunjang yaitu penerapan rendah pada roller conveyor (Tabel 10). Pada kategori sedang yaitu (Baju seragam, dan sarung tangan, Sound system, dan sepatu boot). (Wadah ikan, wadah khusus, timbangan, pallet, motor 3 roda, keranjang dan gerobak dorong) di kategorikan tinggi. Menurut Direktorat Jenderal Perikanan Tangkap (2017) penanganan ikan harus terbuat dari bahan yang kuat, tidak mudah berkarat serta mudah untuk dibersihkan. TPI higienis PPS Cilacap memiliki peralatan antara lain: timbangan, palet yang berada didalam gedung, serta troly, keranjang ikan (trays), sarung tangan dan sepatu boot merupakan peralatan dan perlengkapan yang dimiliki priBadi

Tabel 9. Persepsi Terhadap Peralatan Penunjang Pemasaran Higienis.

Table 9. Perception of Hygienic Facilities/ Marketing Support Equipment.

\begin{tabular}{|c|c|c|c|c|c|}
\hline No & $\begin{array}{c}\text { Uraian/ } \\
\text { Description }\end{array}$ & $\begin{array}{l}\text { Frekuensil } \\
\text { Frequency }\end{array}$ & $\begin{array}{l}\text { Responden/ } \\
\text { Respondents }\end{array}$ & $\begin{array}{l}\text { Persen }(\%) / \\
\text { Percent }(\%)\end{array}$ & $\begin{array}{l}\text { Jumlah Total/ } \\
\text { Total Amount }\end{array}$ \\
\hline \multirow[t]{2}{*}{1.} & \multirow{2}{*}{$\begin{array}{l}\text { Kondisi meja sortir (ditinjau dari } \\
\text { bahan dan konstruksi)/ Sort table } \\
\text { conditions (in terms of materials and } \\
\text { construction) }\end{array}$} & Cukup/ Enough & 22 & 55.0 & $\begin{array}{c}138(\text { Sedang/ } \\
\text { Medium })\end{array}$ \\
\hline & & Baik/ Good & 18 & 45.0 & \\
\hline \multirow[t]{3}{*}{2.} & \multirow{3}{*}{$\begin{array}{l}\text { Kondisi tempat cuci tangan dan } \\
\text { bak cuci kaki (ditinjau dari kontruksi } \\
\text { dan kelengkapan sabun)/ Condition } \\
\text { of hand washing facilities and foot } \\
\text { sinks (in terms of construction and } \\
\text { completeness of soap) }\end{array}$} & Buruk/ Bad & 8 & 20.0 & $\begin{array}{l}118 \text { (Sedang/ } \\
\text { Medium) }\end{array}$ \\
\hline & & Cukup/ Enough & 26 & 65.0 & \\
\hline & & Baik / Good & 6 & 15.0 & \\
\hline \multirow[t]{3}{*}{3.} & \multirow{3}{*}{$\begin{array}{l}\text { Kondisi toilet (ditinjau dari lokasi serta } \\
\text { jumlah)/ Toilet condition (in terms of } \\
\text { location and number of toilets) }\end{array}$} & Buruk/ Bad & 3 & 7.5 & $\begin{array}{c}119 \text { (Sedang/ } \\
\text { Medium })\end{array}$ \\
\hline & & Cukup/ Enough & 35 & 87.5 & \\
\hline & & Baik/ Good & 2 & 5.0 & \\
\hline \multirow[t]{4}{*}{4.} & \multirow{4}{*}{$\begin{array}{l}\text { Kondisi pengelolaan sampah/limbah } \\
\text { (ditinjau dari lokasi dan terpisah } \\
\text { antara organik dan anorganik serta } \\
\text { selalu dikelola)/ Waste management } \\
\text { conditions (in terms of the location and } \\
\text { distribution of organic and inorganic } \\
\text { waste and its management) }\end{array}$} & Buruk/ Bad & 3 & 7.5 & 162 (Tinggi/High) \\
\hline & & Cukup/ Enough & 32 & 80.0 & \\
\hline & & Baik/ Good & 5 & 12.5 & \\
\hline & & & & & \\
\hline \multirow[t]{3}{*}{5.} & \multirow{3}{*}{$\begin{array}{l}\text { Kondisi instalasi dan persediaan air } \\
\text { bersih./ Conditions of water installation } \\
\text { and clean water supply }\end{array}$} & Cukup/ Enough & 2 & 5.0 & 159 (Tinggi/High) \\
\hline & & Baik/ Good & 37 & 92.5 & \\
\hline & & $\begin{array}{l}\text { Sangat baik/ } \\
\text { Very Good }\end{array}$ & 1 & 2.5 & \\
\hline \multirow[t]{2}{*}{6.} & \multirow{2}{*}{$\begin{array}{l}\text { Kondisi Instalasi Penanganan } \\
\text { Air Limbah (IPAL) / Condition of } \\
\text { Wastewater Treatment Plants }\end{array}$} & Buruk/ Bad & 11 & 27.5 & $\begin{array}{c}109 \text { (Sedang/ } \\
\text { Medium) }\end{array}$ \\
\hline & & Cukup/ Enough & 29 & 72.5 & \\
\hline
\end{tabular}


Tabel 10. Persepsi Terhadap Peralatan dan Perlengkapan Pembantu. Table 10. Perception of Auxiliary Equipment.

\begin{tabular}{|c|c|c|c|c|c|}
\hline No. & $\begin{array}{c}\text { Uraian/ } \\
\text { Description }\end{array}$ & $\begin{array}{l}\text { Frekuensi/ } \\
\text { Frequency }\end{array}$ & $\begin{array}{l}\text { Responden/ } \\
\text { Respondents }\end{array}$ & $\begin{array}{l}\text { Persen }(\%) / \\
\text { Percent }(\%)\end{array}$ & $\begin{array}{l}\text { Jumlah Total/ } \\
\text { Total Amount }\end{array}$ \\
\hline \multirow[t]{3}{*}{1.} & \multirow{3}{*}{$\begin{array}{l}\text { Wadah ikan (berbahan kuat } \\
\text { dan mudah dibersihkan)/ Fish } \\
\text { container (made from strong and } \\
\text { easy to clean) }\end{array}$} & Cukup / Enough & 2 & 5.0 & $\begin{array}{l}161 \text { (Tinggi/ } \\
\text { High) }\end{array}$ \\
\hline & & Baik/ Good & 35 & 87.5 & \\
\hline & & $\begin{array}{l}\text { Sangat baik/ } \\
\text { Very Good }\end{array}$ & 3 & 7.5 & \\
\hline \multirow[t]{4}{*}{2.} & \multirow{4}{*}{$\begin{array}{l}\text { Kondisi wadah khusus yang } \\
\text { tahan karat dan kedap air untuk } \\
\text { menampung hasil perikanan } \\
\text { tidak layak jual/ The condition } \\
\text { of special containers that are } \\
\text { rust resistant and waterproof for } \\
\text { sorting fishery products that are } \\
\text { not worth selling }\end{array}$} & Baik/ Good & 6 & 15.0 & $\begin{array}{c}160 \text { (Tinggi/ } \\
\text { High) }\end{array}$ \\
\hline & & & 28 & 70.0 & \\
\hline & & & 6 & 15.0 & \\
\hline & & & & & \\
\hline \multirow[t]{3}{*}{3.} & \multirow{3}{*}{$\begin{array}{l}\text { Kondisi timbangan (ditinjau dari } \\
\text { bahan)/ The condition of the } \\
\text { scales (in terms of ingredients) }\end{array}$} & Baik/ Good & 3 & 7.5 & $\begin{array}{l}160 \text { (Tinggi/ } \\
\text { High) }\end{array}$ \\
\hline & & & 34 & 85.0 & \\
\hline & & & 3 & 7.5 & \\
\hline \multirow[t]{3}{*}{4.} & \multirow{3}{*}{$\begin{array}{l}\text { Kondisi palet (ditinjau dari } \\
\text { bahan dan mudah dibersihkan)/ } \\
\text { Condition of pallets (in terms of } \\
\text { material and easy to clean) }\end{array}$} & Cukup/ Enough & 3 & 7.5 & $\begin{array}{c}167 \text { (Tinggi/ } \\
\text { High) }\end{array}$ \\
\hline & & Baik/ Good & 27 & 67.5 & \\
\hline & & $\begin{array}{l}\text { Sangat baik/ } \\
\text { Very Good }\end{array}$ & 10 & 25.0 & \\
\hline \multirow[t]{2}{*}{5.} & \multirow[t]{2}{*}{$\begin{array}{l}\text { Kondisi Sound System/ Sound } \\
\text { System Conditions }\end{array}$} & Cukup/ Enough & 30 & 75.0 & $\begin{array}{c}130(\text { Sedang/ } \\
\text { Medium })\end{array}$ \\
\hline & & Baik/ Good & 10 & 25.0 & \\
\hline \multirow[t]{3}{*}{6.} & \multirow{3}{*}{$\begin{array}{l}\text { Kondisi Keranjang (Trays) (di } \\
\text { tinjau daribahan kuat dan mudah } \\
\text { dibersihkan)/ Basket Conditions } \\
\text { (Trays) (in terms of material is } \\
\text { strong and easy to clean) }\end{array}$} & Cukup/ Enough & 4 & 10.0 & $\begin{array}{c}161 \text { (Tinggi/ } \\
\text { High) }\end{array}$ \\
\hline & & Baik/ Good & 31 & 77.5 & \\
\hline & & $\begin{array}{l}\text { Sangat Baik/ } \\
\text { Very Good }\end{array}$ & 5 & 12.5 & \\
\hline \multirow[t]{2}{*}{7.} & \multirow[t]{2}{*}{$\begin{array}{l}\text { Kondisi Roller Conveyor/ Roller } \\
\text { Conveyor Conditions }\end{array}$} & $\begin{array}{l}\text { Sangat buruk/ } \\
\text { Very Bad }\end{array}$ & 24 & 60.0 & $\begin{array}{l}56 \text { (Rendah/ } \\
\text { Low) }\end{array}$ \\
\hline & & Buruk/ Bad & 16 & 40.0 & \\
\hline 8. & $\begin{array}{l}\text { Kondisi Perlengkapan Pakaian?/ } \\
\text { Condition of Clothing Equipment? }\end{array}$ & & & & \\
\hline \multirow[t]{2}{*}{$8 a}$. & \multirow{2}{*}{$\begin{array}{l}\text { Baju Seragam dan tanda } \\
\text { pengenal/ Uniform shirts and } \\
\text { identification boards }\end{array}$} & Buruk/ Bad & 20 & 50.0 & $\begin{array}{c}100(\text { Sedang/ } \\
\text { Medium })\end{array}$ \\
\hline & & Cukup/ Enough & 20 & 50.0 & \\
\hline \multirow[t]{2}{*}{$8 b}$. & \multirow[t]{2}{*}{ Sepatu Boot/ Boots } & Cukup/ Enough & 23 & 57.5 & $\begin{array}{l}137 \text { (Sedang/ } \\
\text { Medium) }\end{array}$ \\
\hline & & Baik/ Good & 17 & 42.5 & \\
\hline \multirow[t]{2}{*}{ 8c. } & \multirow[t]{2}{*}{ Sarung Tangan/ Gloves } & Buruk/ Bad & 19 & 47.5 & $\begin{array}{c}101 \text { (Sedang/ } \\
\text { Medium })\end{array}$ \\
\hline & & Cukup/ Enough & 21 & 52.5 & \\
\hline 9 & $\begin{array}{l}\text { Kondisi sarana angkut?/ } \\
\text { Conditions of transport facilities? }\end{array}$ & & & & \\
\hline \multirow[t]{2}{*}{ 9a. } & Gerobak Dorong/ Barrow & Cukup/ Enough & 9 & 22.5 & $\begin{array}{c}151 \text { (Tinggi/ } \\
\text { High) }\end{array}$ \\
\hline & & Baik/ Good & 31 & 77.5 & \\
\hline \multirow[t]{2}{*}{$9 b}$. & Motor 3 Roda/ Tricycle Motor & Baik/ Good & 34 & 85.0 & $\begin{array}{c}166 \text { (Tinggi/ } \\
\text { High) }\end{array}$ \\
\hline & & $\begin{array}{l}\text { Sangat baik/ } \\
\text { Very Good }\end{array}$ & 6 & 15.0 & \\
\hline
\end{tabular}


oleh penguna jasa dari bantuan KKP. Namun Peralatan penunjang seperti roller conveyor, cool box, mesin penghancur es (ice crusher) tidak ada di TPI.

Hasil penerapan menunjukan pada area gudang dan kondisi sapu dinyatakan sedang, selain itu kondisi lainnya dinyatakan tinggi (Tabel 11). Hasil tersebut dikarenakan gudang pada TPI higienis PPS Cilacap tergolong kecil, dan sapu jarang dilihat dan digunakan untuk alat kebersihan. Pada umumnya responden menjawab kondisi peralatan sanitasi tergolong baik.
Hasil menunjukan bahwa penerapan tanda pengenal dinyatakan sedang dan penerapan lainnya dinyatakan tinggi (Tabel 12). TPI higienis PPS Cilacap memiliki aktivitas di pagi, siang, maupun malam hari namun kebanyakan dilakukan di pagi hari dengan aktivitas pembongkaran meliputi: Kapal melapor dan dipandu petugas, setelah kapal sandar tenaga bongkar berseragam membantu proses pembongkaran dengan ikan diestafetkan ke atas dermaga kemudian dimasukan kedalam drum. Saat pembongkaran ada petugas yang melakukan monitoring dan pencatatan data. Akan tetapi terdapat beberapa ketentuan yang tidak sesuai dengan acuan yaitu:

Tabel 11. Persepsi Peralatan dan Perlengkapan Sanitasi.

Table 11. Perception of Sanitary Equipment and Supplies.

\begin{tabular}{|c|c|c|c|c|c|}
\hline No & $\begin{array}{c}\text { Uraian/ } \\
\text { Description }\end{array}$ & $\begin{array}{l}\text { Frekuensi/ } \\
\text { Frequency }\end{array}$ & $\begin{array}{l}\text { Responden/ } \\
\text { Respondents }\end{array}$ & $\begin{array}{l}\text { Persen (\%)/ } \\
\text { Percent (\%) }\end{array}$ & $\begin{array}{l}\text { Jumlah Total/ } \\
\text { Total Amount }\end{array}$ \\
\hline \multirow[t]{2}{*}{1.} & \multirow{2}{*}{$\begin{array}{l}\text { Kondisi gudang penyimpanan } \\
\text { peralatan (ditinjau dari kapasitas)/ } \\
\text { Condition of equipment storage (in } \\
\text { terms of capacity) }\end{array}$} & Cukup/ Enough & 33 & 82.5 & $\begin{array}{c}127 \text { (Sedang/ } \\
\text { Medium) }\end{array}$ \\
\hline & & Baik/ Good & 7 & 17.5 & \\
\hline \multirow[t]{3}{*}{2.} & \multirow{3}{*}{$\begin{array}{l}\text { Kondisi kebersihan Tempat } \\
\text { pemasaran./ Condition of } \\
\text { cleanliness Place of marketing. }\end{array}$} & Cukup/ Enough & 3 & 7.5 & 160 (Tinggi/High) \\
\hline & & Baik/ Good & 34 & 85.0 & \\
\hline & & $\begin{array}{l}\text { Sangat baik/ } \\
\text { Very Good }\end{array}$ & 3 & 7.5 & \\
\hline \multirow[t]{4}{*}{3.} & \multirow{4}{*}{$\begin{array}{l}\text { Kondisi tanda peringatan dilarang } \\
\text { merokok, meludah, makan dan } \\
\text { minum (ditinjau dari letakkan yang } \\
\text { mudah dilihat dengan jelas)./ } \\
\text { Warning signs are prohibited } \\
\text { from smoking, spitting, eating and } \\
\text { drinking (in terms of location that is } \\
\text { easily seen). }\end{array}$} & Cukup/ Enough & 4 & 10.0 & 161 (Tinggi/High) \\
\hline & & Baik/ Good & 31 & 77.5 & \\
\hline & & $\begin{array}{l}\text { Sangat baik/ } \\
\text { Very Good }\end{array}$ & 5 & 12.5 & \\
\hline & & & & & \\
\hline \multirow[t]{3}{*}{4.} & \multirow{3}{*}{$\begin{array}{l}\text { Kondisi fasilitas selasar/kanopi } \\
\text { (ditinjau dari konstruksi)/ Condition } \\
\text { of canopy facilities (in terms of } \\
\text { construction) }\end{array}$} & Cukup/ Enough & 3 & 7.5 & 167 (Tinggi/High) \\
\hline & & Baik/ Good & 27 & 67.5 & \\
\hline & & $\begin{array}{l}\text { Sangat baik/ } \\
\text { Very Good }\end{array}$ & 10 & 25.0 & \\
\hline \multirow[t]{2}{*}{5.} & \multirow{2}{*}{$\begin{array}{l}\text { Kondisi Penyemprot air bertekanan/ } \\
\text { Condition Pressure pressurized } \\
\text { water }\end{array}$} & Baik/ Good & 31 & 77.5 & 169 (Tinggi/High) \\
\hline & & $\begin{array}{l}\text { Sangat baik/ } \\
\text { Very Good }\end{array}$ & 9 & 22.5 & \\
\hline 6. & $\begin{array}{l}\text { Kondisi Peralatan pendukung } \\
\text { kebersihan?/ Cleaning equipment } \\
\text { support conditions? }\end{array}$ & & & & \\
\hline \multirow[t]{3}{*}{$6 a}$. & \multirow[t]{3}{*}{ Sikat / Brush } & Cukup/ Enough & 4 & 10.0 & 159 (Tinggi/High) \\
\hline & & Baik/ Good & 33 & 82.5 & \\
\hline & & $\begin{array}{l}\text { Sangat baik/ } \\
\text { Very Good }\end{array}$ & 3 & 7.5 & \\
\hline \multirow[t]{2}{*}{ 6b. } & \multirow[t]{2}{*}{ Sapu / Broom } & Cukup/ Enough & 19 & 47.5 & $\begin{array}{c}141 \text { (Sedang/ } \\
\text { Medium) }\end{array}$ \\
\hline & & Baik/ Good & 21 & 52.5 & \\
\hline \multirow[t]{2}{*}{$6 c}$. & \multirow[t]{2}{*}{ Tempat sampah / Trash can } & Baik/ Good & 28 & 70.0 & 172 (Tinggi/ High) \\
\hline & & $\begin{array}{l}\text { Sangat Baik/ } \\
\text { Very Good }\end{array}$ & 12 & 30.0 & \\
\hline
\end{tabular}


Tabel 12. Persepsi Aktivitas Pembongkaran.

Table 12. Perception of Demolition Fish Activity.

\begin{tabular}{|c|c|c|c|c|c|}
\hline No & $\begin{array}{c}\text { Uraian/ } \\
\text { Description }\end{array}$ & $\begin{array}{l}\text { Frekuensi/ } \\
\text { Frequency }\end{array}$ & $\begin{array}{l}\text { Responden/ } \\
\text { Respondents }\end{array}$ & $\begin{array}{l}\text { Persen (\%)/ } \\
\text { Percent (\%) }\end{array}$ & $\begin{array}{l}\text { Jumlah Total/ } \\
\text { Total Amount }\end{array}$ \\
\hline \multirow[t]{3}{*}{1.} & \multirow{3}{*}{$\begin{array}{l}\text { Aktivitas pelaporan bongkar kepada } \\
\text { petugas pencatatan dengan dipandu } \\
\text { oleh petugas berwenang/ Reporting } \\
\text { activities unloaded to the recording } \\
\text { officer guided by the authorized } \\
\text { officer }\end{array}$} & Cukup/ Enough & 5 & 12.5 & $\begin{array}{c}161 \text { (Tinggi/ } \\
\text { High) }\end{array}$ \\
\hline & & Baik/ Good & 29 & 72.5 & \\
\hline & & $\begin{array}{l}\text { Sangat Baik / } \\
\text { Very Good }\end{array}$ & 6 & 15.0 & \\
\hline \multirow[t]{5}{*}{2.} & \multirow{5}{*}{$\begin{array}{l}\text { Pengelola dan pengguna jasa ketika } \\
\text { memasuki kawasan pemasaran } \\
\text { mengunakan tanda pengenal atau } \\
\text { seragam/ Manager's activities and } \\
\text { service users when entering the } \\
\text { marketing area using identification } \\
\text { boards and uniforms. }\end{array}$} & $\begin{array}{l}\text { Sangat Buruk/ } \\
\text { Very Bad }\end{array}$ & 4 & 10.0 & $\begin{array}{l}110 \text { (Sedang/ } \\
\text { Medium) }\end{array}$ \\
\hline & & Buruk/ Bad & 16 & 40.0 & \\
\hline & & Cukup/ Enough & 10 & 25.0 & \\
\hline & & Baik/ Good & 6 & 15.0 & \\
\hline & & $\begin{array}{l}\text { Sangat Baik/ } \\
\text { Very Good }\end{array}$ & 4 & 10.0 & \\
\hline \multirow[t]{3}{*}{3.} & \multirow{3}{*}{$\begin{array}{l}\text { Kelancaran aktivitas kapal yang } \\
\text { melakukan bongkar muatan.(ditinjau } \\
\text { dari tempat bersandar)/ Smooth } \\
\text { operation of ships carrying out } \\
\text { loading (in terms of berth capacity). }\end{array}$} & Cukup/ Enough & 3 & 7.5 & $\begin{array}{c}159 \text { (Tinggi/ } \\
\text { High) }\end{array}$ \\
\hline & & Baik/ Good & 35 & 87.5 & \\
\hline & & $\begin{array}{l}\text { Sangat Baik/ } \\
\text { Very Good }\end{array}$ & 2 & 5.0 & \\
\hline \multirow[t]{3}{*}{4.} & \multirow{3}{*}{$\begin{array}{l}\text { Aktivitas tenaga kerja bongkar } \\
\text { muat berseragam dalam membantu } \\
\text { proses bongkar/ Workforce activities } \\
\text { in uniform in helping the process of } \\
\text { unloading }\end{array}$} & Cukup/ Enough & 5 & 12.5 & $\begin{array}{c}161 \text { (Tinggi/ } \\
\text { High) }\end{array}$ \\
\hline & & Baik/ Good & 29 & 72.5 & \\
\hline & & $\begin{array}{l}\text { Sangat Baik/ } \\
\text { Very Good }\end{array}$ & 6 & 15.0 & \\
\hline \multirow[t]{3}{*}{5.} & \multirow{3}{*}{$\begin{array}{l}\text { Ikan ditempatkan dalam wadah } \\
\text { bersih/ Placing fish in clean } \\
\text { containers }\end{array}$} & Cukup/ Enough & 2 & 5.0 & $\begin{array}{c}164 \text { (Tinggi/ } \\
\text { High) }\end{array}$ \\
\hline & & Baik/ Good & 32 & 80.0 & \\
\hline & & $\begin{array}{l}\text { Sangat baik/ Very } \\
\text { Good }\end{array}$ & 6 & 15.0 & \\
\hline \multirow[t]{3}{*}{6.} & \multirow{3}{*}{$\begin{array}{l}\text { Kegiatan bongkar dilakukan sesuai } \\
\text { dengan prinsip Cara Penanganan } \\
\text { Ikan yang Baik (CPIB)/ Unloading } \\
\text { activities are carried out in } \\
\text { accordance with the principles of } \\
\text { Good Fish Management }\end{array}$} & Baik/ Good & 29 & 72.5 & $\begin{array}{c}171 \text { (Tinggi/ } \\
\text { High) }\end{array}$ \\
\hline & & $\begin{array}{l}\text { Sangat baik/ Very } \\
\text { Good }\end{array}$ & 11 & 27.5 & \\
\hline & & & & & \\
\hline \multirow[t]{2}{*}{7.} & \multirow{2}{*}{$\begin{array}{l}\text { Aktivitas monitoring, inspeksi } \\
\text { pembongkaran dan pencatatan data } \\
\text { oleh petugas/ Monitoring activities, } \\
\text { demolition inspection and data } \\
\text { recording by officers }\end{array}$} & Baik/ Good & 29 & 72.5 & $\begin{array}{c}171 \text { (Tinggi/ } \\
\text { High) }\end{array}$ \\
\hline & & $\begin{array}{l}\text { Sangat baik/ Very } \\
\text { Good }\end{array}$ & 11 & 27.5 & \\
\hline
\end{tabular}

1. Tidak diberikannya seragam atau tanda pengenal lain kepada pengguna jasa.

2. Ikan hasil tangkapan seringkali hanya dilempar dari palka menuju dermaga saat

Proses pengangkutan memiliki kategori penerapan tinggi dengan rata-rata responden menyatakan baik pada setiap prosesnya (Tabel 13). Pengangkutan ikan pada TPI higeinis PPS Cilacap sudah memenuhi kriteria yaitu ikan diangkut menuju TPI dengan alat bantu troly, selama pengangkutan ikan terlindung dari sinar matahari. Hanya saja ikan yang didaratkan di TPI higienis adalah mayoritas ikan beku sehingga tidak mengunakan es, akan tetapi suhu masih terjaga.
Hasil menunjukan kondisi penanganan ikan yaitu pemberian label, pensortiran dimeja sortir tidak dilakukan, aktivitas penyusunan diarea display dikategorikan rendah, serta aktivitas pensortiran, penimbangan, aktivitas pemasaran, penanganan ikan didalam rantai dingin, waktu distribusi tergolong dalam kondisi penerapan tinggi seperti pada Tabel 14.

Penanganan ikan di TPI higienis PPS Cilacap dilakukan dengan cara ikan disortir di dermaga saat pembongkaran dengan memilih ikan berdasarkan jenis dan ukuran, kemudian dimasukan kedalam drum, selanjutnya diangkut menuju area penimbangan. Proses lelang tidak 
Tabel 13. Persepsi Aktivitas Pengangkutan Ikan.

Table 13. Perception of Fish Transportation Aktivities.

\begin{tabular}{|c|c|c|c|c|c|}
\hline No. & $\begin{array}{c}\text { Uraian/ } \\
\text { Description }\end{array}$ & $\begin{array}{l}\text { Frekuensi/ } \\
\text { Frequency }\end{array}$ & $\begin{array}{l}\text { Responden/ } \\
\text { Respondents }\end{array}$ & $\begin{array}{l}\text { Persen (\%)/ } \\
\text { Percent (\%) }\end{array}$ & $\begin{array}{l}\text { Jumlah Total/ } \\
\text { Total Amount }\end{array}$ \\
\hline \multirow[t]{3}{*}{1.} & \multirow{3}{*}{$\begin{array}{l}\text { Pengangkutan ikan menuju TPI } \\
\text { dengan alat bantu (conveyor, troll, } \\
\text { gerobak, dll)/ Transportation of fish } \\
\text { to marketing places is assisted using } \\
\text { (conveyors, trolls, carts, etc.) }\end{array}$} & Cukup/ Enough & 4 & 10.0 & $\begin{array}{c}162 \text { (Tinggi/ } \\
\text { High) }\end{array}$ \\
\hline & & Baik/ Good & 30 & 75.0 & \\
\hline & & $\begin{array}{l}\text { Sangat baik/ Very } \\
\text { Good }\end{array}$ & 6 & 15.0 & \\
\hline \multirow[t]{3}{*}{2.} & \multirow{3}{*}{$\begin{array}{l}\text { Pengangkutan ikan terlindung dari } \\
\text { sinar matahari/ Transportation of fish } \\
\text { protected from sunlight }\end{array}$} & Cukup/ Enough & 3 & 7.5 & $\begin{array}{c}164 \text { (Tinggi/ } \\
\text { High) }\end{array}$ \\
\hline & & Baik/ Good & 30 & 75.0 & \\
\hline & & $\begin{array}{l}\text { Sangat baik/ Very } \\
\text { Good }\end{array}$ & 7 & 17.5 & \\
\hline \multirow[t]{2}{*}{3.} & \multirow{2}{*}{$\begin{array}{l}\text { Jumlah es untuk kebutuhan } \\
\text { pendinginan ikan dalam } \\
\text { pengangkutan./ The amount of ice } \\
\text { needed for fish cooling during the } \\
\text { transportation process. }\end{array}$} & Cukup/ Enough & 5 & 12.5 & $\begin{array}{c}155 \text { (Tinggi/ } \\
\text { High) }\end{array}$ \\
\hline & & Baik/ Good & 35 & 87.5 & \\
\hline
\end{tabular}

Tabel 14. Persepsi Kondisi Penanganan Ikan.

Table 14. Perception of Fish Handling Conditions.

\begin{tabular}{|c|c|c|c|c|c|}
\hline No & $\begin{array}{l}\text { Uraian/ } \\
\text { Description }\end{array}$ & $\begin{array}{l}\text { Frekuensi/ } \\
\text { Frequency }\end{array}$ & $\begin{array}{l}\text { Responden/ } \\
\text { Respondents }\end{array}$ & $\begin{array}{l}\text { Persen (\%)/ } \\
\text { Percent (\%) }\end{array}$ & $\begin{array}{l}\text { Jumlah Total/ } \\
\text { Total Amount }\end{array}$ \\
\hline \multirow[t]{3}{*}{1.} & \multirow[t]{3}{*}{$\begin{array}{l}\text { Pensortiran ikan pada meja sortir/ } \\
\text { Fish sorting on the sorting table }\end{array}$} & $\begin{array}{l}\text { Sangat buruk/ Very } \\
\text { Bad }\end{array}$ & 30 & 75.0 & 51 (Rendah/Low) \\
\hline & & Buruk/ Bad & 9 & 22.5 & \\
\hline & & Cukup/ Enough & 1 & 2.5 & \\
\hline \multirow[t]{3}{*}{2.} & \multirow{3}{*}{$\begin{array}{l}\text { Aktivitas pensortiran ikan berjalan/ } \\
\text { Fish sorting activity }\end{array}$} & Cukup/ Enough & 4 & 10.0 & 158 (Tinggi/High) \\
\hline & & Baik/ Good & 34 & 85.0 & \\
\hline & & $\begin{array}{l}\text { Sangat baik/ Very } \\
\text { Good }\end{array}$ & 2 & 5.0 & \\
\hline \multirow[t]{2}{*}{3.} & \multirow{2}{*}{$\begin{array}{l}\text { Aktivitas Penimbangan ikan / Fish } \\
\text { weighing activity }\end{array}$} & Baik/Good & 20 & 50.0 & 180 (Tinggi/High) \\
\hline & & $\begin{array}{l}\text { Sangat baik/ Very } \\
\text { Good }\end{array}$ & 20 & 50.0 & \\
\hline \multirow[t]{3}{*}{4.} & \multirow[t]{3}{*}{$\begin{array}{l}\text { Aktivitas Pemberian label/tanda/ } \\
\text { Labeling / marking activities }\end{array}$} & $\begin{array}{l}\text { Sangat buruk/ Very } \\
\text { Bad }\end{array}$ & 16 & 40.0 & 73 (Rendah/Low) \\
\hline & & Buruk/ Bad & 15 & 37.5 & \\
\hline & & Cukup/ Enough & 9 & 22.5 & \\
\hline \multirow[t]{3}{*}{5.} & \multirow{3}{*}{$\begin{array}{l}\text { Aktivitas Pensusunan ikan } \\
\text { dilakukan area display/ Fish } \\
\text { drafting activities are carried out in } \\
\text { the display area }\end{array}$} & $\begin{array}{l}\text { Sangat buruk/ Very } \\
\text { Bad }\end{array}$ & 7 & 17.5 & 84 (Rendah/Low) \\
\hline & & Buruk/ Bad & 22 & 55.0 & \\
\hline & & Cukup/ Enough & 11 & 27.5 & \\
\hline \multirow[t]{3}{*}{6.} & \multirow{3}{*}{$\begin{array}{l}\text { Proses pemasaran/ Marketing } \\
\text { process. }\end{array}$} & Cukup/ Enough & 3 & 7.5 & 160 (Tinggi/High) \\
\hline & & Baik/ Good & 34 & 85.0 & \\
\hline & & $\begin{array}{l}\text { Sangat baik/ Very } \\
\text { Good }\end{array}$ & 3 & 7.5 & \\
\hline \multirow[t]{2}{*}{7.} & \multirow{2}{*}{$\begin{array}{l}\text { Proses penanganan ikan. (Ditinjau } \\
\text { jumlah penggunaan es/pendingin)/ } \\
\text { Fish handling process. (in terms of } \\
\text { the use of ice / cooler) }\end{array}$} & Baik/ Good & 28 & 70.0 & 172 (Tinggi/High) \\
\hline & & $\begin{array}{l}\text { Sangat baik/ Very } \\
\text { Good }\end{array}$ & 12 & 30.0 & \\
\hline \multirow[t]{3}{*}{8.} & \multirow{3}{*}{$\begin{array}{l}\text { Proses pendistribusian. (Ditinjau } \\
\text { dari waktu setelah lelang selesai)/ } \\
\text { Distribution process. (reviewed } \\
\text { from the time after the auction is } \\
\text { finished) }\end{array}$} & Cukup/ Enough & 4 & 10.0 & 163 (Tinggi/High) \\
\hline & & Baik/ Good & 29 & 72.5 & \\
\hline & & $\begin{array}{l}\text { Sangat baik/ Very } \\
\text { Good }\end{array}$ & 7 & 17.5 & \\
\hline
\end{tabular}


berjalan, karena nelayan sebelumnya sudah melakukan kesepakatan dengan juragan maupun pemborong, sehingga ikan langsung didistribusikan ke dalam truk pengangkut.

\section{Perspektif Penerapan TPI higienis}

TPI dalam salah satu fungsinya adalah memfasilitasi kegiatan pemasaran ikan yang higienis. Penerapan TPI Higienis PPS Cilacap memang tergolong tinggi dengan nilai penerapan di atas 146,67 . Perspektif pengguna jasa terhadap penerapan TPI higienis PPS Cilacap terletak pada fungsi tersebut, pada PPS Cilacap kurang optimal beberapa fungsi utama seperti kondisi faslilitas mulai mengalami kerusakan, tidak adanya fasilitas yang sesuai ketetapan DJPT, tidak melakukan aktivitas pelelangan sehingga fungsi dari berdirinya TPI berkurang. Pengembangan menjadi perlu dilakukan untuk mengoptimalkan penerapan ini, terutama pada fasilitas dan aktivitas nelayan yang perlu di tingkatkan agar menjadikan TPI yang higienis sesuai ketetapan DJPT.

Partisipasi nelayan dalam pelaksanaan pengelolaan sumberdaya, pengendalian harga, pengelolaan lingkungan sangat di butuhkan dalam peningkatan pengelolaan (Sulistyowati \& Karyadi, 2016). Kondisi pendidikan yang rendah juga menyebabkan nelayan memiliki hambatan dalam mengakses berbagai program yang ada (Vibriyanti, 2014). Selanjutnya menurut Renur, Fahrudin, Solihin, \& Kusumastanto (2019) keterlibatan lembaga negara, swasta, maupun masyarakat sangat menentukan keberhasilan pembangunan kelautan.

Penerapan pemasaran higienis memerlukan beberapa tahapan dan keterlibatan berbagai pihak agar dapat berjalan optimal, sehingga pengelola perlu memperbaiki penerapan yang kurang sesuai serta mengarahkan para pengguna jasa supaya dapat menjalankan pemasaran dengan sebaikbaiknya.

\section{KESIMPULAN DAN REKOMENDASI KEBIJAKAN}

\section{Kesimpulan}

Berdasarkan hasil persepsi pengguna jasa (pengelola dan nelayan) terhadap penerapan TPI higienis PPS Cilacap pada fasilitas mayoritas menyatakan dalam penerapan yang tinggi yaitu nilainya di atas 146,67, akan tetapi terdapat beberapa kendala yang dialami yaitu tidak adanya fasilitas penunjang seperti roller conveyor, cool box, mesin penghancur es (ice crusher) kemudian terganggunya pengangkutan karena sebagian lantai rusak serta terlalu miring sehingga menyulitkan petugas bongkar dalam pengangkutanya, ventilasi udara juga menjadi masalah karena tidak adanya alat bantu sirkulasi udara seperti kipas angin atau AC. Aktivitas bongkar dan pengangkutan juga memiliki rata-rata persepsi dalam penerapan tinggi, akan tetapi dalam penanganan ikan yang tidak melakukan aktivitas lelang, sotir dan pelabelan sehingga nilai dari penerapannya rendah yaitu di bawah 93,33. Partisipasi nelayan dalam pemasaran menjadi berkurang akibat tidak diadakannya pelelangan, karena ikan hasil tangkapan sudah dilakukan kesepakatan harga oleh pemilik kapal maupun pedagang besar.

\section{Rekomendasi kebijakan}

Berdasarkan hasil penelitian, maka rekomendasi kebijakan yang diberikan adalah perlunya perbaikan fasilitas yang sudah mengalami kerusakan, serta perlunya penambahan fasilitas untuk memperlancar aktivitas pemasaran. Supaya kegiatan pemasaran mendapat manfaat yang optimal, perlu diperbaiki sistem pemasaran dan perlu meningkatkan pemahaman terhadap pengguna jasa. Upaya tersebut harus sesuai dengan tujuan didirikan TPI higienis yaitu untuk memberikan acuan standar pembangunan TPI higienis di pelabuhan perikanan dan memfasilitasi kegiatan pemasaran ikan yang higienis.

\section{UCAPAN TERIMAKASIH}

Terima kasih kami ucapkan kepada pengguna fasilitas yaitu pihak pengelola maupun nelayan yang sudah meluangkan waktu dan bantuannya selama pengumpulan data di lapangan serta rekan-rekan magister sumber daya pantai 2017 atas masukan dan arahannya untuk penyempurnaan tulisan ini.

\section{PERNYATAAN KONTRIBUSI PENULIS}

Pernyataan status terkait kontributor penulis ini saya cantumkan, berdasarkan kesepemahaman dan kesepakatan atas nilai kontribusi kami terhadap karya tulis yang berjudul "Persepsi Nelayan Terhadap Tempat Pemasaran Ikan Higienis di Pelabuhan Perikanan Samudera Cilacap" dengan sadar dan tanpa paksaan 
apapun, menyatakan bahwa M. Rizqi Hasani sebagai kontributor utama, kemudian Djoko Suprapto dan Dian Wijayanto sebagai kontributor anggota. Demikian pernyataan ini kami buat untuk diketahui oleh semua pihak yang berkepentingan, serta kami telah melampirkan surat pernyataan kontribusi penulis kepada pihak Jurnal Sosial Ekonomi Kelautan dan Perikanan.

\section{DAFTAR PUSTAKA}

Asmal, I., Amina, S. \& Alia, M. (2016). Environmental Sanitation Conditions in the Beba Fish Auction Place (TPI). Procedia - Social and Behavioral Sciences, Vol 227, 778 - 784. DOI: 10.1016/j. sbspro.2016.06.147.

[BPS] Badan Pusat Statistik Kabupaten Cilacap. (2017). Kota Cilacap Dalam Angka. Badan Pusat Statistik. Cilacap.

Codex Alimentarius Commission. (2009). Food Hygiene (Basic Texts) $4^{\text {th }}$ ed.World Health Organization : Food and Agriculture Organization of the United Nations.Rome.

[DJPT] Direktorat Jendral Perikanan Tangkap. (2017). Keputusan Direktur Jendral Perikanan Tangkap Nomor 7/PER-DJPT/2017 tentang Petunjuk Teknis Tempat Pemasaran Ikan (TPI) Higienis di Pelabuhan Perikanan. Kementerian Kelautan dan Perikanan.

ISO 9001:2015. (2015). Quality Management SystemRequirement. BSI Standards Limited. London.

[KBBI] Kamus Besar Bahasa Indonesia. (2018). Kamus Besar Bahasa Indonesia.

Lubis, E. (2012). Pelabuhan Perikanan. Bogor, ID: Press Bogor.

Marcella, E., Prawata, A. G. \& Nasir, N. (2013). Redevelopment Pasar Ikan Higienis di Muara Angke Jakarta.[Skripsi]. Jakarta, ID: Bina Nusantara.

Mintoro, W \& Haryadi B. (2013). Pengelolaan Usaha dan Pengembangan Fungsi Pemasaran Produk Ikan Beku Pada Pt. Anggara Cipta. Citra Agora, Vol 1(2). Retrieved from http://studentjournal. petra.ac.id/index.php/manajemen-bisnis/article/ view/411.

Mussadun, A. F., Kusumastanto,T. \& Kamal,M.M. (2011). Analisis Persepsi Nelayan dalam Pengelolaan Sumberdaya Perikanan Berkelanjutan di Taman Nasional Karimunjawa. Jurnal Tata Loka, Vol 13(2), 70-81. DOI: 10.14710/tataloka.13.2.70-81.

Nastiti, H. G., Wibowo, B.A. \&Dewi, D.A.N.N. (2017). Analisis Kualitas Pelayanan Jasa Kesyahbandaran Dengan Metode Six Sigma Di Pelabuhan Perikanan Samudera (PPS) Cilacap. Jurnal Perikanan Tangkap, Vol 1(3), 1-9.
Ningsih, F. S., Irnad \& Cahyadinata, I. (2017). Kajian Persepsi Nelayan terhadap Kebijakan Perikanan di Kota Bengkulu. Agrisep, Vol 16(2), 133-144.

Nugraheni, H., Rosid, A. \& Boesono, H. (2013). Analisis Pengelolaan Pelabuhan Perikanan Pantai Tasikagung Kabupaten Rembang untuk Peningkatan Produksi Perikanan Tangkap. Journal of Fisheries Resources Utilization Management and Technology, Vol 2(1), 85-94.

Pancawati, Y. D. (2015). Pengembangan Kawasan Minapolitan (Studi Kasus : Pelabuhan Perikanan Samudera Cilacap). Jurnal Pembangunan Wilayah \& Kota, Vol 11(3), 364-375. Doi: 10.14710/pwk.v11i3.17597.

Pelabuhan Perikanan Samudra Cilacap. (2019). Data produksi Pelabuhan Perikanan Samudra Cilacap. Cilacap.

Peraturan Menteri Kelautan dan Perikanan No 52A Tahun 2013. Persyaratan Jaminan Mutu dan Keamanan Hasil Perikanan pada Proses Produksi, Pengolahan dan Distribusi. Jakarta.

Peraturan Pemerintahan No. 57 Tahun 2015. Sistem Jaminan Mutu dan Keamanan Hasil Perikanan serta Peningkatan Nilai Tambah Produk Hasil Perikanan. Jakarta.

Renur, A. N., Fahrudin, A., Solihin, D. \& Kusumastanto, T. (2019). Penataan Kelembagaan Pembangunan Ekonomi Kelautan di Provinsi Maluku. Jurnal Sosial Ekonomi Kelautan dan Perikanan, Vol 14(1), 93-100. DOI: 10.15578/jsekp.v14i1.7004.

Sarwanto, C., Wiyono, E. S., Nurani T. W. \& Haluan, J. (2014). Kajian Sistem Pemasaran Ikan Hasil Tangkapan Nelayan di Kabupaten Gunungkidul, Provinsi Diy. Jurnal Sosial Ekonomi Kelautan dan Perikanan, Vol 9(2), 207-217. DOI: 10.15578/ jsekp.v9i2.1222.

Singh, Y. J., Santhakumar, R., Pandey, D. K., Bharati, H. \& Roy, P. D. (2012). Adoption of Hygienic Fish Handling Practices by Fishermen Indian Res. J. Ext. Edu. Vol. 12(1), 36-38.

Sugiyono. (2012). Metode Penelitian Kuantitatif, kualitatif dan $R \& D$. Bandung: Alfabeta

Sugiyono. (2015). Metode Penelitian Pendidikan (Pendekatan Kuantitatif, kualitatif, dan R\&D). Bandung, ID: Alfabeta.

Suherman, A. (2010). Alternatif Strategi Pengembangan Pelabuhan Perikanan Nusantara Brondong Lamongan Jawa Timur, Jurnal Saintek Perikanan, Vol. 5(2), 65-72.

Suherman, A., Rosyid, A. \& Boesono, H. (2012). Pelabuhan Perikanan. Semarang, ID: Badan Penerbit Universitas Diponegoro.

Sulistyowati \& Karyadi. (2016). Persepsi dan Partisipasi Nelayan pada Pengelolaan Sumberdaya Udang. Agromedia, Vol 34(2), 79-87. 
Sutrisno, E. (2014). Implementasi Pengelolaan Sumber Daya Pesisir Berbasis Pengelolaan Wilayah Pesisir secara Terpadu untuk Kesejahteraan Nelayan. Jurnal Dinamika Hukum, Vol 14(1). DOI: 10.20884/1.jdh.2014.14.1.272.

Vibriyanti, D. (2014). Kondisi Sosial Ekonomi dan Pemberdayaan Nelayan Tangkap Kota Tegal, Jawa Tengah. Jurnal Kependudukan Indonesia, Vol 9(1). doi: 10.14203/jki.v9i1.10.

Wahyudi, A., Lubis, E., \&Pane, A. B. (2017). Strategi Pencegahan Pencemaran Lingkungan Pelabuhan Perikanan: Kasus Pelabuhan Perikanan Nusantara Pelabuhanratu. Jurnal Albacore, Vol 1(2), 139-152.

Zulham, A. (2016). Kapasitas Jaringan Sosial dan Kebijakan Revitalisasi Pelabuhan Perikanan di Pulau Terdepan (Pelajaran dari Revitalisasi Pangkalan Pendaratan Ikan Lugu, Di Kabupaten Simeulue). Jurnal Sosial Ekonomi Kelautan dan Perikanan, Vol 11(2), 201-208. DOI: 10.15578/ jsekp.v11i2.1633. 